\title{
The Impact of Banks and Stock Market Development on Economic Growth in South Africa: an ARDL-bounds Testing Approach
}

\author{
Sheilla Nyasha', Nicholas M. Odhiambo'
}

\begin{abstract}
This paper examines the impact of both bank- and market-based financial development on economic growth in South Africa during the period from 1980 to 2012. Unlike some previous studies, the current study employs means-removed average to construct both bank- and market-based financial development indices. The study uses the newly developed autoregressive distributed lag (ARDL) bounds testing approach to examine this linkage. The empirical results of this study show that there is a positive relationship between bank-based financial development and economic growth in South Africa. The results, however, fail to find any relationship between market-based financial development and economic growth in South Africa. The results apply irrespective of whether the regression analysis is conducted in the short run or in the long run. These results imply that it is bank-based financial development rather than market-based financial development that plays a pivotal role in propelling South Africa's real sector.
\end{abstract}

KEY WORDS: South Africa, Bank-based Financial Development, Market-based Financial Development, Economic Growth

JEL Classification: G10, G20, 016

${ }^{1}$ UNISA - Department of Economics, South Africa

\section{Introduction}

The relationships among banking sector development, stock market development and economic growth have generated a considerable amount of debate for many years among development economists - but with little consensus. Although a growing body of work reflects the close relationship between financial development

Correspondence concerning this article should be addressed to: Sheilla Nyasha, UNISA - Department of Economics, P.O Box 392 UNISA 0003 Pretoria, Pretoria, Gauteng 0003, South Africa, T: +27123956666. E-mail: smagombeyi@yahoo.com and economic growth (Gelb, 1989; King and Levine, 1993a; 1993b; Roubini \& Sala-i-Martin, 1992), alternative views nevertheless exist. Studies that support a positive relationship between financial development and economic growth include those of Schumpeter (2012), Goldsmith (1969), McKinnon (1973), Shaw (1973), King and Levine (1993a) and Odedokun (1996), among others. Studies that support a negative relationship include Van Wijnbergen (1983) and Buffie (1984). Apart from these two groups, there are studies that find either no association or a negligible relationship between financial development and economic 
growth. These include Robinson (1952), Lucas (1988) and Stern (1989).

Previous studies on this subject, however, suffer from four major limitations. First, the majority of previous studies relied on bank-based proxies of financial development, giving market-based proxies little attention. Where the latter studies have been undertaken, the empirical findings have been inconclusive (Akinlo \& Akinlo, 2009; Levine \& Zervos, 1996; Ujunwa \& Salami, 2010), and the evidence suggests that the outcome is both country- and proxy-dependent. Second, the bulk of previous studies have been based mainly on the causal relationship between financial development and economic growth. Very few studies have examined in detail the relative impact of both bank- and market-based financial development on economic growth. Third, the majority of previous studies have mainly used either the residual-based cointegration test associated with Engle and Granger (1987) or the maximum likelihood test based on Johansen (1988) and Johansen and Juselius (1990). Yet, it is now well known that these cointegration techniques may not be appropriate when the sample size is too small (see Odhiambo, 2009). Fourth, some of the previous studies were over-reliant on crosssectional data, which may not have satisfactorily addressed country-specific issues (Ghirmay, 2004).

It is against this backdrop that the current study attempts to examine the relative impact of bank- and market-based financial development on economic growth in South Africa using the newly developed autoregressive distributed lag (ARDL) bounds testing approach. To incorporate various proxies of bank- and market-based financial development in the empirical analysis, the current study employs the method of means-removed average to construct both bank- and market-based financial development indices.

The rest of this paper is organized as follows. Section 2 provides an overview of financial sector reforms in South Africa. Section 3 highlights the theoretical and empirical linkages between bank- and marketbased financial development and economic growth. Section 4 presents the literature review, while section 5 addresses the empirical model specification, estimation technique, and empirical analysis of the regression results. Section 6 concludes.

\section{Financial Sector Reforms in South Africa}

The South African financial system is by far the largest, most developed, and most sophisticated in Africa, and it compares well with the financial systems of the developed world (Bank of International Settlement [BIS], 2012b). Over the past decades, South Africa has established a well-developed banking system and a competitive stock market, which has secured a spot among the top-20 stock markets in the world (Johannesburg Stock Exchange [JSE], 2012). The Johannesburg Stock Exchange (JSE), formed in 1887 and a member of the Federation of International Stock Exchanges since 1963, is the only stock exchange in South Africa, but it is one of the largest stock exchanges in the world in terms of market capitalization.

In the 1990s, South Africa began the financial sector reform process in both the banking sector and the stock market to keep pace with national demands for development and global demands for modernization. In the banking sector, these reforms have focused on improving the legal, regulatory, judiciary and supervisory environments; reducing financial repression, restoring bank soundness, rehabilitating the financial infrastructure; and designing programs to encourage new entrants (BIS, 2012a). On the stock market side, reforms have addressed the legal, regulatory, judiciary and supervisory aspects of the business as well as general modernization of the trading environment.

Over time, these rigorous reforms have given rise to a developed and well-regulated financial system in South Africa. In the banking sector, this is evidenced by growth of private sector credit from $76.4 \%$ of GDP in 1980 to $182.2 \%$ of GDP in 2010, increases in the number of Automated Teller Machines (ATMs) from 22,920 in 2008 to 24,063 in 2010, low levels of nonperforming loans, and strong legal rights (Banking Association South Africa, 2010; World Bank, 2014). Figure 1 illustrates the trends in banking sector growth as shown by credit extension to the private sector in South Africa during the period 1975-2013.

In the stock market, these reforms gave rise to an increased number of listed companies from 401 in 2006 to 417 in 2012 and a remarkable increase in stock market capitalization, total value traded and turnover ratio (JSE, 2014; World Bank, 2014). Figure 2 tracks the performance and growth of the South African stock 


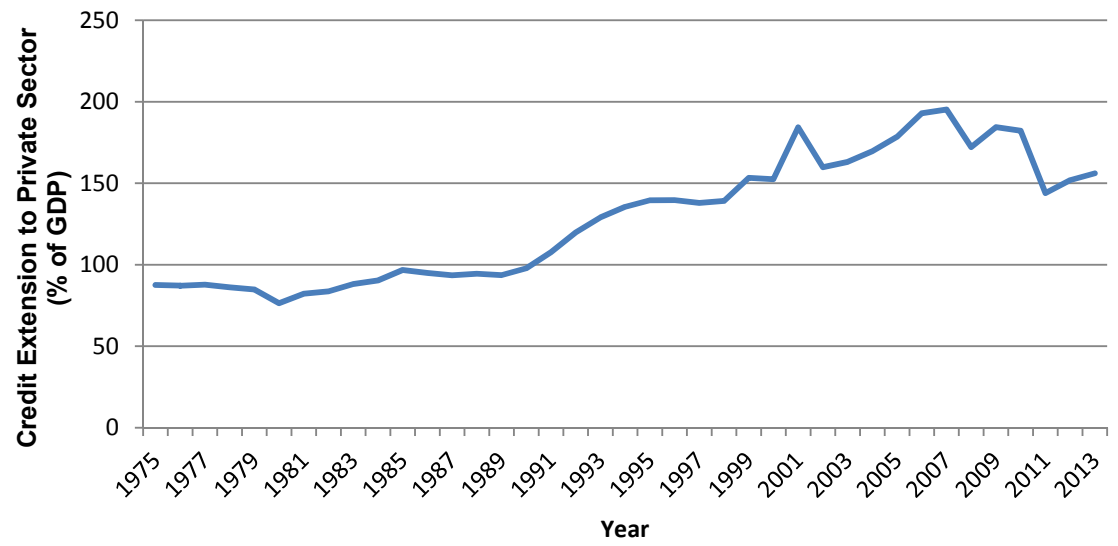

Figure 1. Trend in Banking Sector Growth in South Africa (1975-2013)

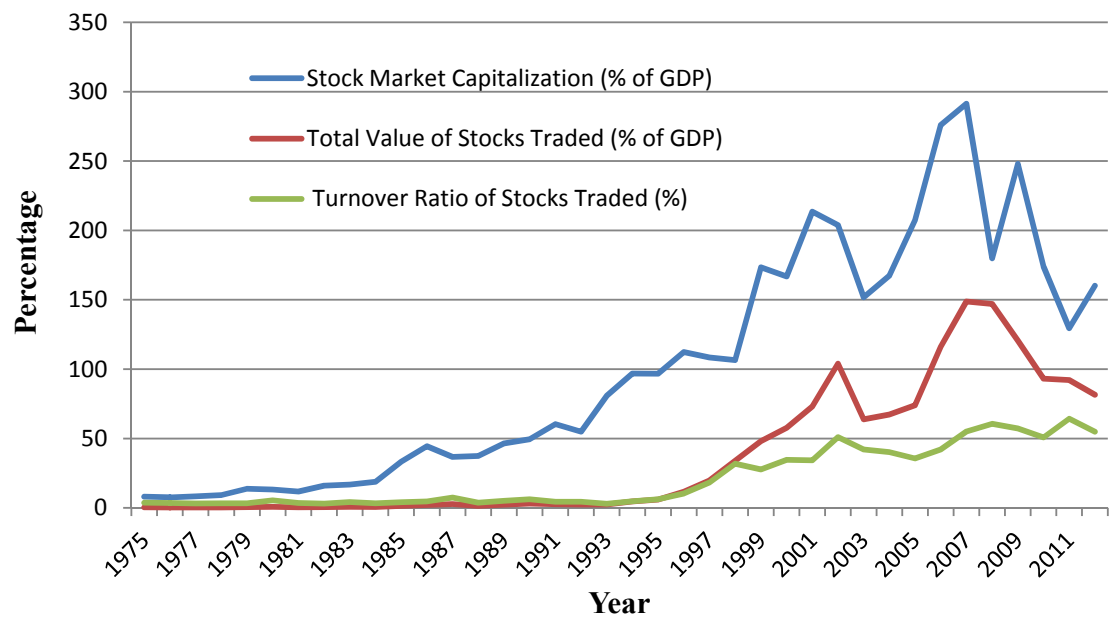

Figure 2. Trends in Stock Market Capitalization, Total Value of Stocks Traded and Turnover Ratio of Stocks Traded in South Africa (1975-2012) 
market during the period 1975-2012 based on stock market capitalization, total value of stocks traded and turnover ratio of stocks traded.

\section{Bank-Based Financial Development, Market-Based Financial Development and Economic Growth}

Generally, a financial system is made up of two components: the bank-based component and the marketbased component. If an economy is driven by financial intermediaries - such as banks and bank-like financial institutions - more than it is driven by financial markets - such as stock and bond markets - that economy's financial system is generally referred to as a bankbased financial system. If securities markets share center stage with banks in driving economic growth via savings mobilization and allocation, corporate control, and risk management, that economy's financial system is generally referred to as a market-based financial system.

Most economists still believe that a bank-based financial system is better than a market-based system. In particular, it is argued that economic growth could be encouraged more in a bank-based system because it can induce longer-term investment in the real sector, whereas investment in a market-based system is too sensitive to stock market prices with short-term investment (Hoshi, Kashyap, \& Scharfstein, 1990).

Without powerful banks to enforce repayment, external investors would be reluctant to finance industrial expansion in countries with underdeveloped institutions. Thus, if banks are not hampered by regulatory restrictions on their activities, they can exploit economies of scale in information processing, moral hazard amelioration through effective monitoring, and in the formation of long-run relationships with firms to ease asymmetric information distortions - thereby boosting economic growth.

The bank-based system can encourage productive investment because it is less affected by unstable financial markets. Even in recessions, the close relationship between banks and businesses can allow firms to continue investment without pushing them into bankruptcy (Odhiambo, 2011). Moreover, it is argued that expensive government policies can be carried out more easily in a bank-based system because it provides governments with more measures with which to intervene in the financial sector (such as credit policy and interest rate regulation) than a market-based system (Pollin, 1995).

However, the bank-based financial system is not without its own disadvantages. According to Odhiambo (2011), a bank-based system is vulnerable to problems, such as inefficient capital allocation, an intimate relationship between banks and firms and a higher debt ratio. Banks may not be effective gatherers or processors of information in new, uncertain situations involving innovative products and processes (Allen \& Gale, 1999). This situation has prompted some to lend support to a market-based financial system, arguing that markets provide a richer set of risk-management tools that permit greater customization of risk-ameliorating instruments.

According to Levine (2004), while bank-based systems may provide inexpensive, basic risk-management services for standardized situations, market-based systems provide greater flexibility through tailor-made products. Thus, as economies mature and require a richer set of risk-management tools and vehicles for raising capital, they may benefit from a concomitant legal and regulatory environment that supports the evolution of market-based activities; otherwise, overall growth may be retarded (Levine, 2004).

\section{Literature Review}

The relationship between financial development and economic growth has received considerable attention in the empirical growth literature, and it is now widely acknowledged that bank-based financial development is positively associated with economic growth. However, there have been inconsistent conclusions because some studies seem to support the existence of a positive relationship between bank-based financial development and economic growth. Other studies - although only a few - conclude that there exists a negative relationship between bank-based financial development and economic growth.

Some of the studies that have examined the relationship between bank-based financial development and economic growth include those of De Gregorio and Guidotti (1995); Odedokun (1996); Ahmed and Ansari (1998); Agbetsiafa (2004); Güryay, Şafakli and Tüzel, (2007); Kargbo and Adamu (2009); and Ahmed 
(2010). All of these studies found a positive relationship between bank-based financial development and economic growth, except for De Gregorio and Guidotti (1995), who found a negative relationship between bank-based financial development and economic growth.

Using the ratio of bank credit to private sector as a measure of bank-based financial development, De Gregorio and Guidotti (1995) examined the empirical relationship between economic growth and financial development in a large cross-country sample. Overall, they found that bank-based financial development is positively related to economic growth. However, its impact tends to vary across countries, and in panel data for Latin America, the relationship was found to be negative.

Odedokun (1996) analyzed the effects of financial development on economic growth in 71 less developed countries (LDCs) using annual data over varying periods from the 1960s through to the 1980s. He found that financial development promotes economic growth in approximately $85 \%$ of these countries. However, a negative association between financial development and economic growth was revealed in at least $15 \%$ of the 71 countries he investigated.

Ahmed and Ansari (1998) investigated the relationship between financial sector development and economic growth in the three major South-Asian economies, India, Pakistan, and Sri Lanka, using pooled data based on time-series and cross-sectional observations. Using M2/GDP and domestic credit to nominal GDP as proxies for bank-based financial development, the results revealed that bank-based financial development has a positive impact on economic growth in these countries.

Agbetsiafa (2004) examined the long-run equilibrium relationship and causal relationship between financial development and economic development in eight sub-Saharan African countries, including South Africa. Using several measures of bank-based financial development - the ratio of broad money to GDP, ratio of bank deposit liabilities to GDP, ratio of claims on the private sector to GDP, share of private sector credits in the domestic credit, and ratio of domestic credit to GDP - the test results confirmed the existence of a long-run relationship between bank-based financial development and economic growth in all eight countries.
Kargbo and Adamu (2009) examined the relationship between financial development and economic growth in Sierra Leone for the period 1970-2008. They used principal component analysis to construct a financial sector development index to proxy development in the financial sector. Using ARDL models, the results showed that financial development exerts a statistically significant positive effect on economic growth.

Ahmed (2010) estimated the relationships among financial liberalization, financial development and growth using panel data and a dynamic time-series analysis for 15 sub-Saharan African countries during the period 1976-2005. Using the ratio of private sector credit to GDP as a proxy for financial development, Ahmed found a positive relationship between this financial development indicator and economic growth in seven of 15 countries. However, when using the ratio of domestic credit to GDP as a measure of financial development, a positive relationship was found in nine of 15 countries, including South Africa.

Hassan, Sanchez and Yu (2011) examined the role of financial development in the economic growth process in low- and middle-income countries using both panel regressions and variance decompositions. The results showed a positive relationship between financial development and economic growth in these developing countries. Adu, Marbuah and Mensah (2013) investigated the long-run growth effects of financial development in Ghana. They found that the effect of financial development on economic growth is sensitive to the choice of proxy used. When credit to the private sector as a ratio to GDP and total domestic credit are used as proxies for financial development, a positive association between financial development and economic growth was confirmed. However, when broad money stock to GDP ratio is considered, the relationship between financial development and economic growth was found to be negative.

Contrary to the conclusions reached in several recent studies that attest to the positive impact of bankbased financial development on economic growth, Ram (1999) found that financial development does not promote economic growth. In his 95-country study, the predominant pattern was that of a negligible or weakly negative association between financial development and economic growth. Using measures 
of bank-based financial development to proxy financial development, Andersen and Tarp (2003) found a weak association between financial development and economic growth in their 74-country study. Similarly, Güryay et al. (2007) found a negligible effect of financial development on economic growth in Northern Cyprus in their finance-growth nexus analysis using the Ordinary Least Squares estimation method.

Regarding market-based financial development, some authors have shown a positive link between market-based financial development and economic growth, while others have argued that even large stock markets are unimportant sources of corporate finance (Mayer, 1988). Although some economists have generally emphasized the central role of financial markets in economic growth, the empirical evidence on the relationship between market-based financial development and economic growth is both scarce and inconclusive.

The empirical studies on the link between marketbased financial development and economic growth, especially in developing countries, are scant. Some of the studies that have examined the relationship between stock market development and economic growth include those of Levine and Zervos (1996); Caporale, Howells and Soliman (2003); Bekaert, Harvey and Lundblad (2005); Adjasi and Biekpe (2006); Nurudeen (2009); Akinlo and Akinlo (2009); Ujunwa and Salami (2010); Bernard and Austin (2011); and Masoud and Hardaker (2012).

Studies by Levine and Zervos (1996), Caporale et al. (2003), Bekaert et al. (2005), Adjasi and Biekpe (2006), Nurudeen (2009), Akinlo and Akinlo (2009) found a positive relationship between market-based financial development and economic growth, while Ujunwa and Salami (2010) and Bernard and Austin (2011) found evidence of positive associations for some countries and evidence of negative associations for other countries.

Levine and Zervos (1996) examined whether there is a strong empirical association between stock market development and long-run economic growth in 41 countries using stock-market capitalization, total value of stocks traded and turnover ratio as proxies for stock market development. The results suggested that stock market development is positively and robustly associated with long-run economic growth. Caporale et al. (2003) re-examined the relationship between stock market development and economic growth in four de- veloping countries of Chile, Korea, Malaysia and the Philippines. Using the market capitalization and value traded ratios as proxies of stock market development, they found evidence of a strong association between stock market development and economic growth in these countries.

Using the turnover ratio as a proxy for stock market development, Bekaert et al. (2005) investigated whether financial liberalization spurs economic growth in a large number of countries. They found a positive association between financial liberalization and economic growth. Adjasi and Biekpe (2006) studied the impact of stock market development on economic growth in 14 African countries in a dynamic panel-data modeling setting. The results generally showed a positive relationship between stock market development and economic growth.

Using an error correction approach, Nurudeen (2009) investigated whether stock market development stimulates economic growth in Nigeria. The econometric results indicated that stock market development, as measured by market capitalization, actually increases economic growth. Akinlo and Akinlo (2009) examined the long-run relationship between stock market development and economic growth in seven sub-Saharan African countries using the ARDL bounds test. The results of the study revealed that stock market development has a significant and positive long-run impact on economic growth.

Ujunwa and Salami (2010) examined the impact of stock market development on long-run economic growth in Nigeria using the Ordinary Least Squares regression. The stock market capitalization, total value of shares traded, and turnover ratio were used as proxies for stock market development. The regression results showed that stock market size and turnover ratios both have a positive impact on economic growth in the country studied. Bernard and Austin (2011) investigated the role of stock market development on economic growth in Nigeria within an Ordinary Least Squares framework during the period from 1994 to 2008. The results showed that stock market development and economic growth are positively associated when the turnover ratio is used as a proxy for stock market development.

Masoud and Hardaker (2012) investigated the relationship between financial development and economic 
growth in 42 emerging markets, including South Africa, over 12 years using an endogenous growth model. Amongst other findings, banking sector and stock market development, as measured by market capitalization and total value traded, were found to play a significant role in the economic growth processes of these emerging markets. However, the turnover ratio was found to be insignificant.

Generally, the literature provides broad empirical evidence of a positive relationship between marketbased finance and economic growth, but there is also some empirical evidence to the contrary. Such empirical evidence emerged from studies by Ujunwa and Salami (2010) and Bernard and Austin (2011), among others. When Ujunwa and Salami (2010) examined the impact of stock market development on long-run economic growth in Nigeria, they found a positive association when stock market development was proxied by stock market size and turnover ratio. They also found evidence of a negative association between stock market development and economic growth in Nigeria when stock market liquidity was used as a proxy for stock market development. In the same vein, Bernard and Austin (2011) found a negative association between stock market development and economic growth in Nigeria using market capitalization and value traded ratios as proxies for stock market development.

\section{Estimation Techniques and Empirical Analysis}

\subsection{Cointegration - ARDL Bounds Testing Procedure}

This study utilizes the newly proposed ARDL bounds testing approach originally introduced by Pesaran and Shin (1999) and later extended by Pesaran, Shin and Smith (2001) to examine the cointegration relationship between bank- and market-based financial development and economic growth. This test has numerous advantages over previous cointegration tests, such as the residual-based technique by Engle and Granger (1987) and Full Maximum Likelihood (FML) test based on Johansen $(1988 ; 1991)$ and on Johansen and Juselius (1990). First, unlike other conventional cointegration techniques, the ARDL bounds testing approach does not impose the restrictive assumption that all the variables under study must be integrated of the same order. In other words, the ARDL approach can be applied to test the existence of a relationship between variables regardless of whether the underlying regressors are integrated of order one [I(1)], order zero $[\mathrm{I}(0)]$, or fractionally integrated.

Second, while conventional cointegration methods estimate the long-run relationship within the context of a system of equations, the ARDL method employs only a single reduced form equation (Pesaran \& Shin, 1999). Third, the ARDL technique generally provides unbiased estimates of the long-run model and valid $t$ statistics - even when some of the regressors are endogenous (Odhiambo, 2008; Odhiambo, 2011). Fourth, while other cointegration techniques are sensitive to the size of the sample, the ARDL test is suitable even when the sample size is small. Thus, the ARDL test has superior small sample properties compared to the Johansen and Juselius (1990) cointegration test (Pesaran \& Shin, 1999). Consequently, the approach is considered very suitable for analyzing the underlying relationship and it has been increasingly used in empirical research in recent years.

The empirical model used in this study to test the impact of financial development, both bank- and market-based, on economic growth is based on Ram (1999), Christopoulos and Tsionas (2004); Majid (2008); and Kargbo and Adamu (2009). The ARDL representation of the model is expressed as follows:

$$
\begin{aligned}
\Delta G R O_{t}=\alpha_{0} & +\sum_{i=1}^{n} \alpha_{i i} \Delta G R O_{t-i}+\sum_{i=0}^{n} \alpha_{2 i} \Delta B F D_{t-i}+\sum_{i=0}^{n} \alpha_{3 i} \Delta M F D_{t-i}+\sum_{i=0}^{n} \alpha_{4 i} \Delta I N V_{t-i} \\
& +\sum_{i=0}^{n} \alpha_{5 i} \Delta S A V_{t-i}+\sum_{i=0}^{n} \alpha_{6 i} \Delta T O P_{t-i}+\sigma_{1} G R O_{t-1}+\sigma_{2} B F D_{t-1}+\sigma_{3} M F D_{t-1} \\
& +\sigma_{4} I N V_{t-1}+\sigma_{5} S A V_{t-1}+\sigma_{6} T O P_{t-1}+\varepsilon_{1 t}
\end{aligned}
$$

where GRO is the growth rate of real gross domestic product, a proxy for economic growth; BFD is an index of bank-based financial development, which is a means removed average of M2, M3 and credit provided to the private sector by financial intermediaries, a proxy for bank-based financial development (see also, Demirguc-Kunt and Levine, 1996); MFD is an index of market-based financial development, which is a means removed average of stock market capitalization, stock market traded value and stock market turnover, a proxy for market-based financial development (see also Demirguc-Kunt and Levine, 1996); INV is a share 
of the investment in gross domestic product; SAV is a share of savings in gross domestic product; TOP is trade openness; $\alpha_{0}$ is a constant; $\alpha_{1}-\alpha_{6}$ and $\sigma_{1}-\sigma_{6}$ are regression coefficients; $\Delta$ is the difference operator; $n$ is the lag length; and $\varepsilon_{\mathrm{t}}$ is the white noise error term.

The error correction model is specified as follows:

$$
\begin{aligned}
\Delta G R O_{t}=\alpha_{0} & +\sum_{i=1}^{n} \alpha_{1 i} \Delta G R O_{t-i}+\sum_{i=0}^{n} \alpha_{2 i} \Delta B F D_{t-i}+\sum_{i=0}^{n} \alpha_{3 i} \Delta M F D_{t-i}+\sum_{i=0}^{n} \alpha_{4 i} \Delta I N V_{t-i} \\
& +\sum_{i=0}^{n} \alpha_{5 i} \Delta S A V_{t-i}+\sum_{i=0}^{n} \alpha_{6 i} \Delta T O P_{t-i}+\xi_{1} E C M_{t-1}+\varepsilon_{t}
\end{aligned}
$$

\subsection{Data Sources}

This study utilized annual time-series data covering the period from 1980 to 2012. The annual data used in the study were obtained from the World Bank Economic Indicators (World Bank, 2014), except the market-based financial development proxies (stock market capitalization, stock market traded value, and stock market turnover) for the period 1980 to 1988 , which were obtained from the Johannesburg Stock Exchange (Johannesburg Stock Exchange, 2014). All the model estimations were computed using Microfit 5.0 software.

\subsection{Stationarity Tests}

Before any analysis was made, the variables were first tested for stationarity using the Dickey-Fuller generalized least squares (DF-GLS) and Phillips-Perron (PP) tests. To attend to possible structural breaks within the dataset, the Perron 1997 unit root test (PPU-Root) was utilized as the third unit root testing method.

The DF-GLS lag length was selected automatically by SIC, the PP truncation lag was selected automatically on the Newey-West bandwidth, and the PPURoot break years were also automatically selected; these dates ranged from 1987 to 2006, depending on the variable (see Appendix 1). The results of DF-GLS, PP and PPU-Root stationarity tests for the variables are presented in Table 1.

The results reported in Tables 1 show that after differencing the variables once, all the variables were confirmed to be stationary. Although the ARDL test does not require the pretesting of variables, the unit root test provides guidance as to whether ARDL is applicable because it is only applicable to the analysis of variables that are integrated of order zero $[\mathrm{I}(0)]$ or one $[\mathrm{I}(1)]$. In this instance, the variables are conclusively stationary after being differenced once; hence, the ARDL bounds testing procedure can be satisfactorily performed.

\subsection{Cointegration and ARDL-ECM Model}

In this section, the long-run relationship between the variables in the general model is examined using the ARDL bounds testing procedure. The first step is to obtain the order of lags on the first differenced variables in equations (1) by using the Akaike Information Criterion and the Schwartz Bayesian Criterion. This is followed by the application of a bounds F-test to equation (1) to establish a long-run relationship between the variables under study. The results of the bounds Ftest are reported in Table 2.

The results of the F-test suggest that there exists a long-run relationship between GRO, BFD, MFD, INV, SAV and TOP. Following the estimation of the ARDL model and the use of AIC or SIC for optimal lag-length selection, the SIC-based ARDL $(1,1,0,1,0,1)$ model was selected because it is more parsimonious than the AIC-based model. The long-run results of the selected model are reported in Table 3 Panel A and the shortrun results are reported in Table 3 Panel $\mathrm{B}$.

The long-run results reported in Table 3 (Panel A) show that the coefficient of bank-based financial development is statistically significant at the $1 \%$ level and positive, as expected. However, the coefficient of market-based financial development is statistically insignificant. These results show that an increase in bank-based financial development leads to an increase in economic growth in the long run. These results compare favorably with the results of various studies on the same subject (see, among others, Agbetsiafa, 2004; Kargbo Adamu, 2009; Masoud \& Hardaker, 2012). Odedokun (1996) and Agbetsiafa (2004) found bank-based financial development, proxied by various banking sector development indicators, to have a positive impact on economic growth, while Masoud and Hardaker (2012) found stock market development, as measured by the turnover ratio, to have no significant impact on economic growth in 42 emerging markets, including South Africa.

The other long-run results also show that the coefficients of investment (INV) and savings (SAV) are statistically significant. While the coefficient of savings is positive, implying the existence of a positive long-run relationship between savings and economic growth, 
Table 1. Stationarity Tests for all Variables

\section{Dickey-Fuller Generalized Least Square (DF-GLS)}

\begin{tabular}{|c|c|c|c|c|}
\hline \multirow[t]{2}{*}{ Variable } & \multicolumn{2}{|c|}{ Stationarity of all Variables in Levels } & \multicolumn{2}{|c|}{ Stationarity of all variables in First Difference } \\
\hline & Without Trend & With Trend & Without Trend & With Trend \\
\hline GRO & $-3.253^{* * *}$ & $-3.927^{* * *}$ & - & - \\
\hline BFD & -1.708 & -2.500 & $-5.650 * * *$ & $-5.799 * * *$ \\
\hline MFD & -0.863 & -2.503 & $-6.699 * * *$ & $-6.825^{* * *}$ \\
\hline INV & -1.139 & -2.235 & $-3.042^{* * *}$ & $-3.933^{* * *}$ \\
\hline SAV & -1.177 & -2.260 & $-5.052^{* * *}$ & $-6.181^{* * *}$ \\
\hline TOP & -1.503 & -2.034 & $-5.366^{* * *}$ & $-5.783^{* * *}$ \\
\hline
\end{tabular}

\section{Phillips-Perron (PP)}

\begin{tabular}{|c|c|c|c|c|}
\hline \multirow{2}{*}{ Variable } & \multicolumn{2}{|c|}{ Stationarity of all Variables in Levels } & \multicolumn{2}{|c|}{ Stationarity of all variables in First Difference } \\
\hline & Without Trend & With Trend & Without Trend & With Trend \\
\hline GRO & $-4.155^{* * *}$ & $-4.531^{* * *}$ & - & - \\
\hline BFD & -1.756 & -2.168 & $-5.909 * * *$ & $-5.902^{* * *}$ \\
\hline MFD & -1.267 & -2.481 & $-6.620^{* * *}$ & $-6.661^{* * *}$ \\
\hline INV & -1.918 & -1.325 & $-3.475^{* *}$ & $-3.828^{* *}$ \\
\hline SAV & -2.474 & -2.315 & $-6.216^{* * *}$ & $-7.113^{* * *}$ \\
\hline TOP & -2.118 & -2.847 & $-5.714^{* * *}$ & $-5.754^{* * *}$ \\
\hline \multicolumn{5}{|c|}{ Perron 1997 (PPU-Root) } \\
\hline \multirow[t]{2}{*}{ Variable } & \multicolumn{2}{|c|}{ Stationarity of all Variables in Levels } & \multicolumn{2}{|c|}{ Stationarity of all variables in First Difference } \\
\hline & Without Trend & With Trend & Without Trend & With Trend \\
\hline GRO & -3.024 & -4.932 & $-6.653^{* * *}$ & $-6.931^{* * *}$ \\
\hline BFD & -2.472 & -3.414 & $-8.573^{* * *}$ & $-8.532^{* * *}$ \\
\hline MFD & -2.725 & -4.933 & $-7.767^{* * *}$ & $-7.896^{* * *}$ \\
\hline INV & -2.412 & -3.182 & $-5.866^{* *}$ & $-5.714^{* *}$ \\
\hline SAV & -4.453 & -4.091 & $-7.522^{* * *}$ & $-9.567^{* * *}$ \\
\hline TOP & -3.813 & -3.702 & $-5.868^{* *}$ & $-5.743^{* *}$ \\
\hline
\end{tabular}

Note: ${ }^{*}{ }^{* *}$ and ${ }^{* * *}$ denotes stationarity at $10 \%, 5 \%$ and $1 \%$ significance levels. 
Table 2. Bounds F-test for Cointegration

\begin{tabular}{|c|c|c|c|c|c|c|}
\hline Dependent Variable & \multicolumn{4}{|c|}{ Function } & \multicolumn{2}{|c|}{ F-statistic } \\
\hline GRO & \multicolumn{4}{|c|}{$\mathrm{F}(\mathrm{GRO} \mid \mathrm{BFD}, \mathrm{MFD}, \mathrm{INV}, \mathrm{SAV}, \mathrm{TOP})$} & \multicolumn{2}{|c|}{$4.859^{* * *}$} \\
\hline \multicolumn{7}{|c|}{ Asymptotic Critical Values } \\
\hline \multirow{3}{*}{$\begin{array}{l}\text { Pesaran et al. (2001), } \\
\text { p. 300, Table CI(iii) } \\
\text { Case III }\end{array}$} & \multicolumn{2}{|c|}{$1 \%$} & \multicolumn{2}{|c|}{$5 \%$} & \multicolumn{2}{|c|}{$10 \%$} \\
\hline & $\mathrm{I}(0)$ & $\mathrm{I}(1)$ & $\mathrm{I}(0)$ & $\mid(1)$ & $\mathrm{I}(0)$ & $\mathrm{I}(1)$ \\
\hline & 3.41 & 4.68 & 2.62 & 3.79 & 2.26 & 3.35 \\
\hline
\end{tabular}

Note: ${ }^{* *}$ denotes statistical significance at $1 \%$ level

Table 3. Results of ARDL Model

Panel A: Long-run Coefficients - Dependent variable is GRO

\begin{tabular}{|c|c|c|c|c|}
\hline Regressor & Coefficient & Standard Error & T-Ratio & Prob \\
\hline C & $-7.27^{* * *}$ & 1.79 & -4.06 & 0.001 \\
\hline BFD & $0.12^{* * *}$ & 0.04 & 3.30 & 0.003 \\
\hline MFD & 0.01 & 0.01 & 0.73 & 0.474 \\
\hline INV & $-0.16^{*}$ & 0.07 & -2.17 & 0.041 \\
\hline SAV & $0.46^{* * *}$ & 0.10 & 4.83 & 0.000 \\
\hline TOP & -0.09 & 0.06 & -1.16 & 0.122 \\
\hline
\end{tabular}

Panel B: Short-run Coefficients - Dependent variable is $\Delta G R O ; \Delta=$ first difference operator

\begin{tabular}{|c|c|c|c|c|c|}
\hline Regressor & Coefficient & Standard Error & \multicolumn{2}{|l|}{ T-Ratio } & Prob \\
\hline$\triangle \mathrm{BFD}$ & $0.05^{* *}$ & 0.02 & \multicolumn{2}{|l|}{2.23} & 0.035 \\
\hline$\triangle \mathrm{MFD}$ & 0.01 & 0.02 & \multicolumn{2}{|l|}{0.73} & 0.472 \\
\hline$\triangle I N V$ & $0.74^{* *}$ & 0.29 & \multicolumn{2}{|l|}{2.56} & 0.017 \\
\hline$\triangle \mathrm{SAV}$ & $0.66^{* * *}$ & 0.13 & \multicolumn{2}{|l|}{5.16} & 0.000 \\
\hline$\triangle \mathrm{TOP}$ & 0.06 & 0.07 & \multicolumn{2}{|l|}{0.95} & 0.353 \\
\hline $\operatorname{Ecm}(-1)$ & $-0.73^{* * *}$ & 0.15 & \multicolumn{2}{|l|}{-4.76} & 0.000 \\
\hline R-Squared & 0.862 & \multicolumn{2}{|c|}{ R-Bar-Squared } & 0.805 & \\
\hline SE of Regression & 1.220 & \multicolumn{2}{|c|}{ F-Stat F(7,24) } & \multicolumn{2}{|l|}{$22.815[0.000]$} \\
\hline Residual Sum of Squares & 32.768 & \multicolumn{2}{|c|}{ DW statistic } & \multicolumn{2}{|l|}{1.905} \\
\hline Akaike Info. Criterion & -55.785 & \multicolumn{2}{|c|}{ Schwarz Bayesian Criterion } & -63.114 & \\
\hline
\end{tabular}

Note: ${ }^{*}, * *$ and ${ }^{* * *}$ denotes stationarity at $10 \%, 5 \%$ and $1 \%$ significance levels.

$\triangle G R O=G R O-G R O(-1) ; \triangle B F D=B F D-B F D(-1) ; \triangle M F D=M F D-M F D(-1) ; \Delta I N V=I N V-I N V(-1) ; \triangle S A V=S A V-S A V(-1) ; \triangle T O P=T O P-T O P(-1)$ 
Table 4. ARDL - VECM Diagnostic Tests

\begin{tabular}{ll}
\hline LM Test Statistic & Results \\
\hline Serial Correlation: CHSQ(1) & $0.165[0.799]$ \\
Functional Form: CHSQ(1) & $0.572[0.449]$ \\
Normality: CHSQ (2) & $0.279[0.870]$ \\
Heteroscedasticity: CHSQ (1) & $1.364[0.243]$ \\
\hline
\end{tabular}

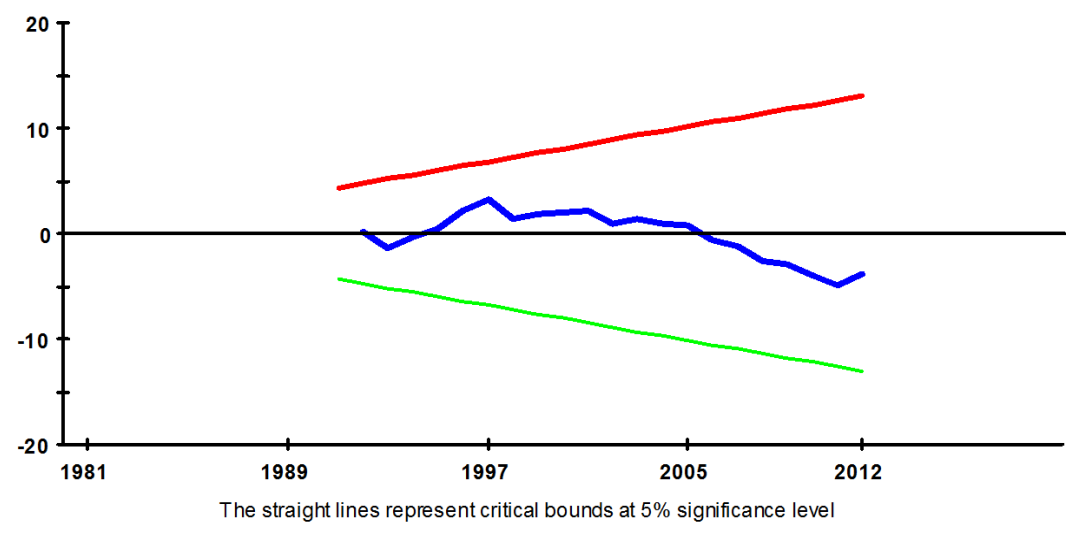

Figure 3. Cumulative Sum of Recursive Residuals Plot

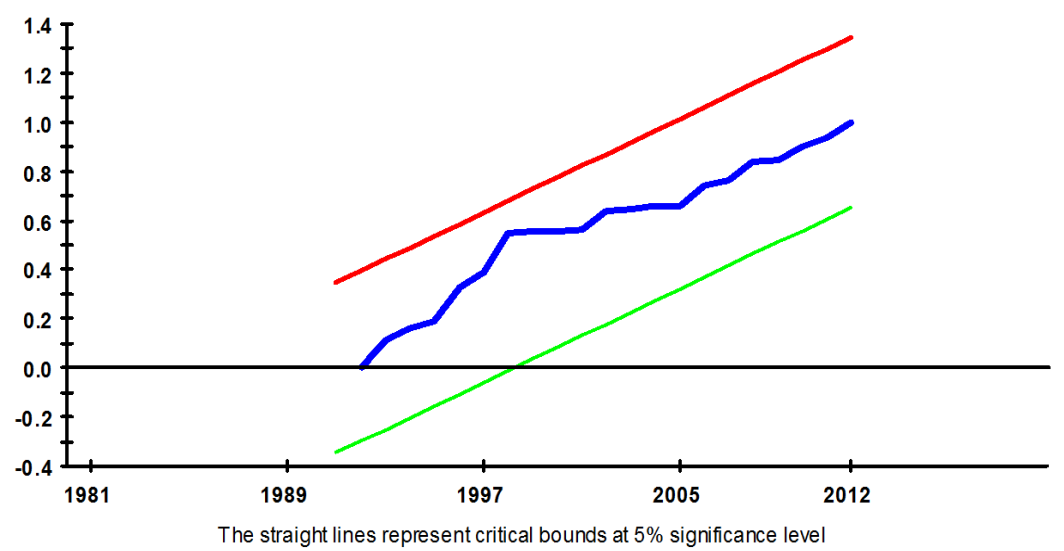

Figure 4. Cumulative Sum of Squares of Recursive Residuals Plot 
the coefficient of investment is negative - contrary to the expectations of this study. The coefficient of trade openness (TOP), however, is found to be statistically insignificant.

The short-run dynamics of the model are shown in Table 3 (Panel B). As in the case of the long-run results, these results show that the coefficient of bank-based financial development is both positive and statistically significant, as expected. This implies that an increase in the bank-based financial development levels leads to an increase in economic growth in the South African economy over the short run. However, the coefficient of market-based financial development is statistically insignificant, implying that over the short run, marketbased financial development and economic growth are not related and that any changes in market-based financial development may not necessarily lead to changes in economic growth. These results imply that in South Africa, it is bank-based financial development rather than market-based financial development that is pivotal in propelling economic growth.

The results reported in Table 3 (Panel B) also show that the coefficients of investment (INV) and savings (SAV) are both positive and statistically significant, implying that investment and savings both have a positive impact on the growth of the South African economy over the short run. The coefficient of ECM $(-1)$ is also found to be negative and statistically significant, as expected.

Although the South African stock market is one of the top 20 stock markets worldwide, this study has found no significant impact of stock market development on economic growth in South Africa. This could be because bank-based financial development in the study country has a more significant impact on economic growth than stock markets, which would imply that when both variables are incorporated into the growth equation, stock market development becomes insignificant. Alternatively, the small sample size, prompted by the unavailability of sufficiently longterm time-series data, could explain the observed negligible impact of stock market development on economic growth in South Africa.

Based on both the short- and long-run results, bank-based financial sector development was found to stimulate economic growth. Thus, the policy implication of these results is that for the South African econ- omy, immense efforts to promote the development of the banking sector are recommended to stimulate the real sector.

The results displayed in Table 4 show that the model passes all the diagnostic tests performed for serial correlation, functional form, normality and heteroscedasticity.

Figures 3 and 4 show plots of the cumulative sum of recursive residuals (CUSUM) and cumulative sum of squares of recursive residuals (CUSUMQ). The reported CUSUM and CUSUMQ are within the boundaries, showing that the model is stable and confirms the stability of the long-run coefficients of the regressors.

\section{Conclusion}

In this paper, we have examined the relative impact of bank- and market-based financial development on economic growth in South Africa during the period from 1980 to 2012. The South African financial sector is by far the largest, most developed, and most sophisticated in Africa, and it compares well with financial systems of the developed world. Although a number of studies have been conducted on this subject, the majority of the previous studies were mainly based on the causal relationship between financial development and economic growth. Very few studies have examined in detail the relative impact of both bank- and marketbased financial development on economic growth. In addition, the majority of the previous studies relied mainly on the residual-based cointegration test associated with Engle and Granger (1987) and the maximum likelihood test based on Johansen (1988) and Johansen and Juselius (1990). Yet, it is now known that these techniques may not be appropriate when the sample size is too small. Unlike the majority of previous studies, the current study uses the newly developed ARDL bounds testing approach to examine this linkage. In addition, the study employs the method of means removed averages to construct both bank- and marketbased financial development indices. The empirical results of this study show that there is a positive relationship between bank-based financial development and economic growth in South Africa. The results apply irrespective of whether the regression analysis is conducted over the short or long run. However, the results further reveal that there is no relationship between market-based financial development and eco- 
nomic growth in South Africa irrespective of whether the regression analysis is conducted over the short or long run. These results imply that it is bank-based financial development rather than market-based financial development that plays a pivotal role in propelling South Africa's real sector, both in the short run and in the long run.

\section{References}

Adjasi, C. K. D., \& Biekpe, N. B. (2006). Stock market development and economic growth: The case of selected African countries. African Development Bank, 18 (1), 144-161.

Adu, G., Marbuah, G., \& Mensah, J. T. (2013). Financial development and economic growth in Ghana: Does the measure of financial development matter? Review of Development Finance, 3 (4), 192-203.

Agbetsiafa, D. (2004). The finance growth nexus: evidence from sub-Saharan Africa. Savings and Development, 28 (3), 271-288.

Ahmed, A. D. (2010). Financial liberalization, financial development and growth linkages in Sub Saharan African countries. An empirical investigation. Studies in Economics and Finance, 27 (4), 314-339.

Ahmed, S. M., \& Ansari, M. I. (1998). Financial sector development and economic growth: The SouthAsian experience. Journal of Asian Economics, 9 (3), 503-517.

Akinlo, A. E., \& Akinlo, O. O. (2009). Stock market development and economic growth: Evidence from seven sub-Sahara African countries. Journal of Economics and Business, 61 (2), 162-171.

Allen, F., \& Gale, D. (1999). Diversity of opinion and the financing of new technologies. Journal of Financial Intermediation, 8 (1-2), 68-89.

Andersen, T. B., \& Tarp, F. (2003). Financial liberalization, financial development and economic growth in LDCs. Journal of International Development, 15 (2), 189-209.

Bank of International Settlement. (2012b). The South African banking sector: An overview of the past 10 years. Retrieved from www.bis.org

Bank of International Settlement. (2012a). Address by the Governor of the South African Reserve Bank (1997) on financial sector reforms and their implications for the banking industry in South Africa. Retrieved from www.bis.org
Banking Association South Africa. (2010). South African banking sector overview. Retrieved from www. banking.org.za

Bekaert, G., Harvey, C. R., \& Lundblad, C. (2005). Does financial liberalization spur growth? Journal of Financial Economics, 77 (1), 3-55.

Bernard, A. U., \& Austin, A. (2011). The role of stock market development on economic growth in Nigeria: A time series analysis. African Research Review, 5 (6), 213-230.

Buffie, E. F. (1984). Financial repression, the new structuralists, and stabilisation policy in semiindustrialized economics. Journal of Development Economics, 14 (3), 305-322.

Caporale, G. M., Howells, P. G. A. , \& Soliman, A. M. (2003). Stock market development and economic growth: The causal linkage. Journal of Economic Development, 29 (1), 33-50.

Christopoulos, D. K., \& Tsionas, E. G. (2004). Financial development and economic growth: evidence from panel unit root and cointegration tests. Journal of Development Economics, 73 (1), 55-74.

De Gregorio, J., \& Guidotti, P. E. (1995). Financial development and economic growth. World Development, 23 (3), 433-448.

Demirguc-Kunt, A., \& Levine, R. (1996). Stock market development and financial intermediaries: stylized facts. World Bank Economic Review, 10 (2), 291-321.

Engle, R. F., \& Granger, C. J. (1987). Cointegration and error-correction - representation, estimation and testing. Econometrica, 55 (2), 251-278.

Gelb, A. H. (1989). Financial policies, growth, and efficiency (Working Paper No. 202). World Bank.

Ghirmay, T. (2004). Financial development and economic growth in sub-Saharan African countries: Evidence from time series analysis. African Development Review, 16 (3), 415-432.

Goldsmith, R. W. (1969). Financial Structure and Development. New Haven, CT: Yale University Press.

Güryay, E., Şafakli, O. V., \& Tüzel, B. (2007). Financial development and economic growth: Evidence from Northern Cyprus. International Research Journal of Finance and Economics, 8 (2), 57-62.

Hassan, K. M., Sanchez, B., \& Yu, J. (2011). Financial development and economic growth: new evidence from panel data. The Quarterly Review of Economics and Finance, 51 (1), 88-104. 
Hoshi, T., Kashyap, A., \& Scharfstein, D. (1990). The role of banks in reducing the costs of financial distress in Japan. Journal of Financial Economics, 27 (1), 67-88.

Johannesburg Stock Exchange. (2012). History and company overview. Retrieved from http://www. jse.co.za/Home.aspx

Johannesburg Stock Exchange. (2014). Historical market data. Retrieved from https://www.jse.co.za/ services/market-data/historical-data

Johansen, S. (1988). Statistical analysis of cointegration vectors. Journal of Economic Dynamics and Control, 12 (2-3), 231-254.

Johansen, S. (1991). Estimation and hypothesis testing of cointegration vectors in Gaussian vector Autoregressive Models. Econometrica, 59 (6), 15511580 .

Johansen, S., \& Juselius, K. (1990). Maximum likelihood estimation and inference on cointegration - with applications to the demand for money. Oxford Bulletin of Economics and Statistics, 52 (2), 169-210.

Kargbo, S. M., \& Adamu, P. A. (2009). Financial development and economic growth in Sierra Leone. West African Journal of Monetary and Economic Integration, 9 (2), 30-61.

King, R. G., \& Levine, R. (1993a). Finance and growth: Schumpeter might be right. Quarterly Journal of Economics, 108 (3), 717-737.

King, R. G., \& Levine, R. (1993b). Finance, entrepreneurship, and growth: theory and evidence. Journal of Monetary Economics, 32 (3), 513-542.

Levine, R. (2004). Finance and growth: theory and evidence (Working Paper No. 10766). National Bureau of Economic Research.

Levine, R., \& Zervos, S. (1996). Stock market development and long run growth. World Bank Economic Review, 10 (2), 323-340.

Lucas, R. (1988). On the mechanism of economic development. Journal of Monetary Economics, 22 (1), 3-42.

Majid, M. S. A. (2008). Does financial development matter for economic growth in Malaysia? An ARDL bound testing approach. Journal of economic Cooperation, 29 (1), 61-82.

Masoud, N., \& Hardaker, G. (2012). The impact of financial development on economic growth: analy- sis of emerging market countries. Studies in Economics and Finance, 29 (3), 148-173.

Mayer, C. (1988). New issues in corporate finance. European Economic Review, 32 (5), 1167-1183.

McKinnon, R. I. (1973). Money and capital in economic development. Washington, D.C: Brookings Institution.

Nurudeen, A. (2009). Does stock market development raise economic growth? Evidence from Nigeria. The Review of Finance and Banking, 1 (1), 15-26.

Odedokun, M. O. (1996). Alternative econometric approaches for analyzing the role of the financial sector in economic growth: time-series evidence from LDCs. Journal of Development Economics, 50 (1), 119-146.

Odhiambo, N. M. (2008). Financial depth, savings and economic growth in Kenya: A dynamic causal linkage. Economic Modelling, 25 (4), 704-713.

Odhiambo, N. M. (2009). Savings and economic growth in South Africa: A multivariate causality test. Journal of Policy Modeling, 31 (5), 708-718.

Odhiambo, N. M. (2011). Financial intermediaries versus financial markets: A South African experience. International Business \& Economics Research Journal, 10 (2), 77-84.

Perron, P. (1997). Further evidence on breaking trend functions in macroeconomic variables. Journal of Econometrics, 80 (2), 355-385.

Pesaran, M. H., \& Shin, Y. (1999). An autoregressive distributed lag modeling approach to cointegration analysis In S. Strom (Ed.), Econometrics and economic theory in the 20th century. The Ragnar Frisch Centennial Symposium Econometric Society monographs (No. 31) (pp. 371-413). Cambridge, UK: Cambridge University Press.

Pesaran, M. H., Shin, Y., \& Smith, R. (2001). Bound testing approaches to the analysis of level relationship. Journal of Applied Econometrics, 16 (3), 289-326.

Pollin, R. (1995). Financial structures and egalitarian economic policy. New Left Review, 214, 26-61.

Ram, R. (1999). Financial development and economic growth: Additional evidence. Journal of Development Studies, 35 (4), 164-174.

Roubini, N., \& Sala-i Martin, X. (1992). Financial repression and economic growth. Journal of Development Economics, 39 (1), 5-30. 
Robinson, J. (1952). The generalisation of the general theory, In J. Robinson (Eds.), The Rate of interest and other essays (pp. 69-142). London, UK: Macmillan.

Schumpeter, J. A. (2012). The theory of economic development. An inquiry into profits, capital, credit, interest, and the business cycle (16th ed.). New Brunswick, NJ: Transaction Publishers.

Shaw, E. S. (1973). Financial deepening in economic development. New York, NY: Oxford University Press.

Stern, N. (1989). The economics of development: a survey. Economic Journal, 99 (397), 597-685.

Ujunwa, A., \& Salami, O. P. (2010). Stock market development and economic growth: Evidence from Nigeria. European Journal of Economics, Finance and Administrative Sciences, 25, 44-53.

Van Wijnbergen, S. 1983. Credit policy, inflation and growth in a financially repressed economy. Journal of Development Economics, 13 (1), 45-65.

World Bank. (2014). World Bank Development Indicators. Retrieved from http://data.worldbank.org/ topic/financial-sector 
Appendix: Break period for variable under PPU-Root Test

\begin{tabular}{|c|c|c|c|c|}
\hline \multirow[t]{2}{*}{ Variable } & \multicolumn{2}{|c|}{ Break Period of all Variables in Levels } & \multicolumn{2}{|c|}{ Break Period of all variables in First Difference } \\
\hline & Without Trend & With Trend & Without Trend & With Trend \\
\hline GRO & 1988 & 1988 & 1987 & 1988 \\
\hline BFD & 1998 & 2005 & 1991 & 1991 \\
\hline MFD & 2001 & 2006 & 2006 & 2001 \\
\hline INV & 1985 & 1989 & 1986 & 2005 \\
\hline SAV & 1990 & 1990 & 1986 & 1986 \\
\hline TOP & 1989 & 1989 & 2002 & 2002 \\
\hline
\end{tabular}

